\section{Validity of a 2-item screening tool to identify families at risk for food insecurity in Brazil}

\author{
Validade de um instrumento de triagem com \\ dois itens para identificar famílias em risco de \\ insegurança alimentar no Brasil
}

\author{
Validez de un instrumento de 2-ítems para \\ identificar a familias en riesgo de inseguridad \\ alimentaria en Brasil
}

\author{
Ana Poblacion 1 \\ Ana Maria Segall-Corrêa 2 \\ John Cook 3 \\ Jose Augusto de Aguiar Carrazedo Taddei 1
}

\begin{abstract}
This manuscript aimed to develop a brief 2-item screening tool to identify Brazilian households that include families with children at risk for food insecurity. Psychometric analyses including sensitivity, specificity, positive and negative predictive value, accuracy, and ROC curves were used to test combinations of questions to determine the most effective screener to assess households at risk for food insecurity when compared to a gold standard scale. Participants included Brazilian National Survey of Demography and Health on Women and Children (PNDS) surveyed households with a valid Brazilian Food Insecurity Scale (EBIA) response. The sample included 3,920 households representing 11,779,686 households when expanded using PNDS sample weights. With overall prevalence of food insecurity at $21 \%$, a Brazilian 2-item food-insecurity screen showed sensitivity of 79.31\%, specificity of $92.95 \%$, positive predictive value of $74.62 \%$, negative predictive value of $94.5 \%$ and ROC area $86.13 \%$. This screen also presented high convergent validity for children's nutrition and health variables when compared with the gold standard, the EBIA full scale. Based on its ability to detect households at risk for food insecurity, a 2-item screening tool is recommended for widespread adoption as a screening measure throughout Brazil, especially when rapid decision-making has been made fundamental, as under the COVID-19 pandemic. This screener can enable providers to accurately identify families at risk for food insecurity and promptly intervene to prevent or ameliorate adverse health and developmental consequences associated with food insecurity and swiftly respond to crises.
\end{abstract}

Food Security; Hunger; Nutritional Epidemiology; Child Development

\author{
Correspondence \\ A. Poblacion \\ Universidade Federal de São Paulo. \\ Rua dos Otonis 839, São Paulo, SP 04040-032, Brasil, \\ anapoblacion@yahoo.com.br \\ 1 Universidade Federal de São Paulo, São Paulo, Brasil. \\ 2 Programa de Alimentação, Nutrição e Cultura, \\ Fundação Oswaldo Cruz, Brasília, Brasil. \\ 3 Boston University, Boston, U.S.A.
}




\section{Introduction}

In 2004, the Brazilian Food Insecurity Scale (EBIA) 1 was adapted to Portuguese and validated using the U.S. Household Food Security Survey Module (HFSSM) as model. Since then, EBIA has been included in some national health surveys and a few smaller regional or local studies, capturing food insecurity information intermittently.

Results from national datasets allow for population food-insecurity prevalence surveillance, and its association with socioeconomic, demographic and health related variables generates scientific evidence to inform public policies. Since national surveys are developed primarily for generating national prevalence estimates, data collected from representative samples of the national population are not meant to identify individual food-insecure households for immediate intervention. To fill in this gap, data from regional or local surveys are considered; however, these studies are not always conducted systematically.

In 2010, Hager et al. ${ }^{2}$ validated a screening tool to identify individual households with young children at risk for food insecurity. The Hunger Vital Sign (HVS) is a 2-question food insecurity screening instrument, derived from the HFSSM, showing high sensitivity, specificity, and convergent validity. The HVS measures families' concerns about access to food much the way health care providers check other key vital signs, such as pulse and blood pressure. Healthcare and social service providers, community-based outreach workers, teachers, and others that work with families with young children can use the HVS to identify households that may be in immediate need of food assistance. This tool has been recommended by the American Academy of Pediatrics 3 for use at all well-child visits, and in 2017, the Centers for Medicare and Medicaid Services incorporated the HVS into its Accountable Health Communities Screening Tool 4. In 2015, the HVS was validated for use among youth and adolescents 5 , and in 2017 it was also validated for use among adults 6 . Others have suggested the use of the HVS within healthcare systems for older adult populations 7 , and it also has been translated to multiple languages 8 .

The development and validation of a Brazilian 2-item screening tool based on the EBIA would allow for identification of families currently at risk for food insecurity while also functioning as a local or regional risk-monitoring tool. These capacities are especially useful during crises such as the one posed by COVID-19, for targeting effective evaluation of health care and nutrition interventions, following the Brazilian health services' priorities. Besides, inclusion of a 2-item screening tool for food insecurity in routine health center visits could strengthen the Brazilian Food and Nutrition Surveillance System (SISVAN) by helping to identify families living in food-insecure households in a more timely way. If the 2 -item screening tool proves to be as effective for the Brazilian population as it has been for the United States, it will complement national/regional data collected by the extended EBIA questionnaire. By generating individual/local data, a Brazilian "Hunger Vital Sign" could allow more timely social policy solutions to reduce food insecurity while permanent changes in government-supported social infrastructures are being designed and implemented. Thus, this study aimed to develop a brief 2-item screening tool to identify Brazilian households that include families with children at risk for food insecurity.

\section{Methods}

Gold standard: EBIA at the Brazilian National Survey of Demography and Health on Women and Children

The third edition of the Brazilian National Survey of Demography and Health on Women and Children (PNDS 2006/2007) aimed to describe the health and nutrition of reproductive-age women (15-49 years old) and their children under 5 years of age. This survey also gathered data on social, economic and cultural factors, including food insecurity at the household level using the EBIA. The PNDS 2006/2007 used a complex probability sampling design, with national representativeness with data collected in two stages: the primary sampling unit was the census area and the secondary sampling unit the household. The sample included only non-institutionalized private households, from ten 
independent sampling strata obtained from the combination of five geographic regions and urban/ rural areas within each region. Eligible households were selected at random, considering the number of census areas in each region, and if they were located in urban or rural areas. The survey methodology, including sample design and selection, data collection procedures, data consistency, weighting and expansion techniques for complex samples and ethical/human subjects' aspects are described elsewhere 9 .

The PNDS 2006/2007 used a modified EBIA, containing 16 questions, with question 5 ("In the last three months, did you or other adults in the household ever cut the size of your meals or skip meals because there wasn't enough money to buy food?") split into two parts ("In the last three months, did you or other adults in the household ever cut the size of your meals because there wasn't enough money to buy food?", and "In the last three months, did you or other adults in the household ever skip meals because there wasn't enough money to buy food?"). For analysis purposes, as recommended by PNDS, these two questions were recombined as a negative answer ("no") when both parts had negative responses, or "do not know" to one part, and "no" to the other. For other response combinations, the answer was marked positively ("yes").

The number of questions affirmed indicates the level of food security in a household, and is the basis for classifying households in one of the four food security categories. In this version of EBIA, the four food security categories for households with children under 18 years are: Food Secure $(0$ questions affirmed); Mild Food Insecurity (1-5 questions affirmed); Moderate Food Insecurity (6-10 questions affirmed); and Severe Food Insecurity (11-15 questions affirmed) 10. All questions in the EBIA refer to the three months preceding the survey. Prevalence estimates and inferential analyses were conducted using the food security status variable dichotomized as households not considered at risk, including the Food Secure and Mild Food Insecurity categories (Food Security) and households at risk, comprising Moderate and Severe Food Insecurity categories (Food Insecurity). The Food Insecurity composite category represents the greater severity of food scarcity in a household, in which adults and children could be experiencing hunger during the three months preceding the interview. When responses were "do not know" to questions regarding conditions of access to food (1st to 4th questions), the interview was terminated and that record was eliminated $(n=17$, corresponding to $0.35 \%$ of sample).

\section{Eligibility and selection criteria for the study sample}

For this research, eligible children included those $\leq 59$ months of age, living in the same house as their mothers, with the EBIA filled correctly, totaling 4,800 children. Because the study unit is the household, PNDS replicated EBIA answers for all individuals living in a particular household. Therefore, to avoid duplication of sample unit representation in the data analysis, only one child was selected per household. When a woman had more than one child under 5 years old, only the oldest child was maintained in the sample $(\mathrm{n}=784)$. When there were two or more children under 5 years old, who were children of different mothers residing in the same household, the younger child/children was/ were excluded $(n=61)$. In addition, when there were twins in the household, we retained in the sample only the twin who was born in better condition, using birth weight as reference. We excluded the twin with the lower birth weight noted on the child's official Brazilian health record card. If the card was unavailable, birth weight reported by the mother was used. In the absence of these data, the younger twin was excluded $(n=35)$ using the variable stating the children's order of birth. Selection criteria followed a rationale of maintaining in the sample children who had lived longer under respective environmental conditions. After exclusions, 3,920 children (one per household) were available for analysis representing 11,779,686 households when expanded using PNDS sample weights.

\section{Development of the 2-item screening tool}

Seven steps were involved in the development of the screen: estimating of sensitivity, specificity, positive and negative predictive values (with ROC curves), accuracy and convergent validity. Sensitivity identifies the screen's ability to correctly identify food-insecure households (minimizing false negatives), whereas specificity describes the screen's ability to correctly identify food-secure households 
(minimizing false positives). Positive predictive value shows the percent of those identified by the screen as food insecure that are actually food insecure, negative predictive value shows the percent of those not identified by the screen as food insecure that are actually food secure. The area under a ROC curve exposes the screen test's ability to diagnose households with and without food insecurity, and the accuracy shows the degree to which the screen correctly describes food insecurity. And the convergent validity assesses the relationships between screening results and variables theoretically related to food insecurity, such as socioeconomic, demographic and health variables.

Combinations of 1, 2, 3 and 4 questions were tested as possible screening tools using contingency table procedures. Sensitivity, specificity, positive and negative predictive value, and accuracy were estimated and a ROC curves was plotted for each combination of candidate screening items. The combination of two questions that exhibit the best sensitivity, specificity and convergent validity was selected as the screen.

\section{Convergent validity}

Socioeconomic and child nutrition and health variables were used to test the convergent validity of candidate screens. To test the hypothesis that children under 5 years living in a moderate or severe food-insecure household would have significantly worse health conditions when compared with their food-secure peers, we performed Poisson regression analysis 11 in two separate sets of analyses, one using the gold standard and the second using the 2 -item screening tool. Variables with $\mathrm{p}<0.20$ in bivariate analyses with the food security predictor or the health outcome variable were considered eligible for inclusion as potentially confounding variables in the multivariate analysis. The final model contained only the strongest associated variables, with $\mathrm{p}<0.05$, using a backward stepwise elimination technique. Dependent, health outcome variables were selected according to their association with food insecurity in a previous study 12. All models were adjusted for Macro-region, urban-rural classification, living conditions, economic status, cash transfer program (CTP) participation, maternal education, marital status, number of children in the household, child's gender and age. These covariates were chosen on the basis of theoretical and bivariate associations with both food insecurity and the outcomes.

Macro-region was dichotomized to contrast Brazilian development areas, with the North and Northeast identified as less-developed regions and Central, Southeast and South as more-developed regions. Urban or rural household status was also included as a covariate. Representing household's economic status, the Brazilian Economic Classification Criterion (Brazilian Association of Research Companies; http://www.abep.org/criterioBrasil.aspx, accessed on 11/Mar/2020) was used as an indicator of families' purchasing power. A dichotomized variable was used grouping household economic status in wealthier classes - from A1 to C2, and less wealthy classes - D/E. A dichotomized Living conditions variable was considered "adequate" if the household contained all five of the following items: indoor availability of water, water connected to a sewage system, shingle or concrete slab on house roofs, brickwork walls and wooden floor, vinyl floor covering, ceramic tiles, cement or carpet floor, otherwise the household Living conditions were classified as "inadequate". CTP participation was dichotomized to indicate if a resident of the household received at least one of the seven available social safety-net programs in 2006.

Maternal education was dichotomized as “ $\leq 8$ years of study" or "more than 8 years". This categorization of education attainment is equivalent to graduation from middle school or not, respectively. The Marital status variable followed PNDS criteria: when a woman was formally married or was in a stable union, she was considered "having a partner". If a woman was single, widowed, separated, legally separated, or divorced, she was considered "without a partner". The Number of children living in the same household was dichotomized as "1-2 children" or " $\geq 3$ children".

Dietary intake was obtained using the PNDS qualitative food frequency questionnaire (FFQ) composed of 20 typical Brazilian foods. The frequency of children's consumption of each food was reported by the mother for the seven days preceding the interview 13 . For children aged 6 months to 5 years variables were coded as follows: four types of meat were chosen from the FFQ to reflect the child's consumption of meat (beef/pork, liver, chicken, and fish). A dichotomous variable was created indicating that either a child had eaten meat at least one time per day in the past seven days (coded 
as "at least $1 \mathrm{x} /$ day"), or a child had eaten meat but not every day in the past seven days (coded as "not every day"). To compose the Fruits \& vegetables variable, three food groups were selected from the FFQ. Daily consumption of fruits and vegetables (from the Brazilian questionnaire: "frutas" "verduras", "legumes") indicates the child consumed at least three healthy foods daily, as recommended by the Brazilian Ministry of Health 14,15. A dichotomous variable was created indicating either that a child had eaten fruits and vegetables every day in the past seven days (coded as "every day"), or that a child had eaten fruits and vegetables but not every day in the past seven days (coded as "not every day"). Children under 6 months of age were included in the analysis by adding children in the "every day" category, who had not eaten fruits and vegetables or meat on any given day in the past seven days, implying that breastfeeding or formula feeding were the only forms of food they had eaten.

Anthropometric measurement equipment, training and standardization of interviewers, supervision and quality control of measurement techniques used to obtain all measurements followed standard PNDS procedures 16,17. Weight-for-age categories, described in Z-scores (WAZ), were based on the World Health Organization (WHO) standards 18. For analysis purposes, a dichotomous variable named Nutritional status was created considering a child "underweight" if WAZ $<-2.0$, and "not underweight" if WAZ $\geq-2.0$. Hospitalizations were based on mother's report of if children were hospitalized for diarrhea or pneumonia at least once in the 12 months before the interview (coded as "yes").

\section{Data analysis}

To merge and analyze PNDS 2006/2007 datasets, Stata/IC 14 (https://www.stata.com) was used. To correctly reflect the stratification and clustering effects of the complex sampling design, all analyses were performed using the complex survey command (svy) to represent the Brazilian population. However, to avoid overestimating associations in subgroups, sample weights were only used in descriptive analysis 11. Chi-square tests with a second-order Rao-Scott correction 19 were used in descriptive bivariate analysis of associations of socioeconomic, demographic, biological variables with disaggregated food insecurity. Unadjusted and adjusted multivariate analysis used Poisson regression.

\section{Ethical standards}

This study was approved by the Ethics Reasearch Committee of the São Paulo Federal University/ Hospital São Paulo (n. 080567/2016).

\section{Results}

A sample of 3,920 households was selected for analysis representing 11,779,686 households. Table 1 describes socioeconomic, demographic and child nutrition and health variables by food security status. As expected, food insecure households were more prevalent in the North and Northeast regions and rural areas. Most of families living in food-insecure households were from low economic strata, had inadequate living conditions and participated in safety net programs. Most mothers living in food-insecure households reported less than 8 years of education, being without a partner, and having three or more children, who were prominently older than 2 years of age. More children living in food-insecure households did not eat meat, or fruits and vegetables every day. Food insecurity was also associated with undernutrition (WAZ < -2.0) and children's hospitalizations during the year preceding the interview.

\section{Food insecurity screen}

After detailed examination of each EBIA positive response using cross tabulations, the combination of questions 2 and 4 showed higher sensitivity, specificity, positive and negative predictive values and ROC area when compared with the gold standard. Question number 2 in the EBIA ("Nos últimos três meses a comida acabou antes que você tivesse mais dinheiro para comprar mais?") corresponds to HFSSM 
Table 1

Description of demographic, socioeconomic and biological variables by food security status in households with children younger than 5 years. Brazil, 2006/2007.

\begin{tabular}{|c|c|c|c|c|}
\hline Characteristics & $\begin{array}{c}\text { Households } \\
\text { n (\%) }\end{array}$ & $\begin{array}{l}\text { Food security * } \\
\quad \%(95 \% \mathrm{Cl})\end{array}$ & $\begin{array}{c}\text { Food insecurity * } \\
\%(95 \% \mathrm{Cl})\end{array}$ & p-value ** \\
\hline Macro-region & 3,920 & & & 0.0001 \\
\hline Central/Southeast/South & $2,406(61.4)$ & $89.9(86.6 ; 92.4)$ & $10.1(7.6 ; 13.4)$ & \\
\hline North/Northeast & $1,514(38.6)$ & $69.3(66.1 ; 72.3)$ & $30.7(27.7 ; 33.9)$ & \\
\hline Urban-rural classification & 3,920 & & & 0.0025 \\
\hline Urban & $2,601(66.3)$ & $83.8(81.0 ; 86.2)$ & $16.2(13.8 ; 18.9)$ & \\
\hline Rural & $1,319(33.7)$ & $76.5(72.2 ; 80.3)$ & $23.5(19.7 ; 27.9)$ & \\
\hline Economic status *** & 3,919 & & & 0.0001 \\
\hline $\mathrm{A} 1$ to $\mathrm{C} 2$ & $2,463(62.8)$ & $90.6(88.6 ; 92.3)$ & $9.4(7.7 ; 11.4)$ & \\
\hline $\mathrm{D} / \mathrm{E}$ & $1,456(37.1)$ & $66.0(61.4 ; 70.4)$ & $34.0(29.6 ; 38.6)$ & \\
\hline Living conditions & 3,918 & & & 0.0001 \\
\hline Adequate & $1,894(48.4)$ & $87.8(85.1 ; 90.0)$ & $12.2(10.0 ; 14.9)$ & \\
\hline Inadequate & $2,024(51.6)$ & $73.8(69.8 ; 77.5)$ & $26.2(22.5 ; 30.2)$ & \\
\hline Cash transfer program & 3,917 & & & 0.0001 \\
\hline Not receive & $2,714(69.3)$ & $88.1(85.9 ; 89.9)$ & $11.9(10.1 ; 14.1)$ & \\
\hline Receive & $1,203(30.7)$ & $67.0(61.7 ; 71.9)$ & $33.0(28.2 ; 38.3)$ & \\
\hline Maternal education (years) & 3,896 & & & 0.0001 \\
\hline$>8$ & $1,578(40.5)$ & $92.1(89.7 ; 94.0)$ & $7.9(6.1 ; 10.3)$ & \\
\hline $0-8$ & $2,318(59.5)$ & $74.3(70.8 ; 77.5)$ & $25.7(22.5 ; 29.2)$ & \\
\hline Marital status & 3,918 & & & 0.0114 \\
\hline With partner & $3,336(85.1)$ & $83.8(81.7 ; 85.8)$ & $16.2(14.3,18.3)$ & \\
\hline Without partner & $582(14.9)$ & $74.8(65.9 ; 82.0)$ & $25.2(18.0 ; 34.1)$ & \\
\hline Number of children & 3,920 & & & 0.0001 \\
\hline $1-2$ & $2,905(74.1)$ & $85.2(82.5 ; 87.5)$ & $14.8([12.5 ; 17.5)$ & \\
\hline$\geq 3$ & $1,015(25.9)$ & $70.8(66.2 ; 74.9)$ & $29.2(25.1 ; 33.8)$ & \\
\hline Gender of children & 3,920 & & & 0.7894 \\
\hline Female & $1,894(48.3)$ & $82.2(78.5 ; 85.3)$ & $17.8(14.7 ; 21.5)$ & \\
\hline Male & $2,026(51.7)$ & $82.7(79.9 ; 85.1)$ & $17.3(14.9 ; 20.1)$ & \\
\hline Age of children (months) & 3,920 & & & 0.0253 \\
\hline$<24$ & 1,299 (33.1) & $86.3(81.4 ; 90.1)$ & $13.7(9.9 ; 18.6)$ & \\
\hline$\geq 24$ & $2,621(66.9)$ & $80.2(77.7 ; 82.6)$ & $19.8(17.4 ; 22.3)$ & \\
\hline Meat & 3,826 & & & 0.0267 \\
\hline At least $1 x /$ day & $2,510(65.6)$ & $84.1(81.6 ; 86.4)$ & $15.9(13.7 ; 18.4)$ & \\
\hline Not every day & $1,316(34.4)$ & $79.4(75.0 ; 83.3)$ & $20.6(16.7 ; 25.0)$ & \\
\hline Fruits \& vegetables & 3,884 & & & 0.0093 \\
\hline Every day & $513(13.2)$ & $92.4(83.9 ; 96.6)$ & $7.6(3.4 ; 16.2)$ & \\
\hline Not every day & 3,371 (86.8) & $80.7(78.3 ; 82.9)$ & $19.3(17.1 ; 21.7)$ & \\
\hline Nutritional status (WAZ) & 3,646 & & & 0.0140 \\
\hline$\geq-2.0$ & $3,551(97.4)$ & $82.3(79.9 ; 84.6)$ & $17.7(15.5 ; 20.2)$ & \\
\hline$<-2.0$ & $95(2.6)$ & $67.9(52.7 ; 80.0)$ & $32.1(20.0 ; 47.3)$ & \\
\hline Hospitalization & 3,920 & & & 0.0353 \\
\hline No & $3,712(94.7)$ & $82.8(80.3 ; 85.1)$ & $17.2(14.9 ; 19.7)$ & \\
\hline Yes & $208(5.3)$ & $74.2(65.0 ; 81.6)$ & $25.9(18.4 ; 35.0)$ & \\
\hline
\end{tabular}

95\%Cl: 95\% confidence interval; WAZ: weight-for-age categories, described in Z-scores.

Note: household variables: macro-region, urban-rural classification, economic status, living-conditions, cash transfer program, maternal education, marital status and number of children. Children's variables: gender, age, meat, fruits \& vegetables intake, nutritional status and hospitalization.

* Food security includes food security and mild food insecurity categories. Food insecurity includes moderate and severe categories;

** Qui-square test with Rao-Scott correction;

*** According to the Brazilian Association of Research Companies (http://www.abep.org/criterioBrasil.aspx, accessed on 11/Mar/2020). 
question Q2: “In the past 12 months, the food that (I/we) bought just didn't last, and (I/we) didn't have money to get more?"); and EBIA's question number 4 ("Nos últimos três meses, você teve que se arranjar com apenas alguns alimentos para alimentar os moradores com menos de 18 anos, porque o dinheiro acabou?") corresponds to HFSSM question Q4: "In the past 12 months, did (you or other adults in your household) ever cut the size of your meals or skip meals because there wasn't enough money for food?”.

Prevalence of food insecurity assessed by EBIA was $20.7 \%$ and the Brazilian 2-item food-insecurity screen comprised by questions 2 and 4 provided prevalence of $22 \%$, sensitivity of $79.31 \%$, specificity of $92.96 \%$, positive predictive value of $74.62 \%$, and negative predictive value of $94.5 \%$. Its accuracy was $90.13 \%$ and the area under the ROC curve was of $86.13 \%$ (Tables 2 and 3 ).

Convergent validity analyses using Poisson logistic regression models compared results conducted with the EBIA and the Brazilian 2-item food-insecurity screen separately. The 2-item screening tool discriminated nutrition and health outcomes associated with living in food-insecure households similarly to the EBIA 15-item gold standard. Using the Brazilian 2-item food-insecurity screen, when compared with children living in food secure households, children in food insecure households were 1.1 and 1.5 times more likely to not eat meat or fruits and vegetables every day, respectively. Moreover, children living in food insecure households were 1.3 times more likely to have their weight-forage lower than -2.0 Z-scores and 1.4 times more likely to be hospitalized by diarrhea or pneumonia. Showing similar results of high nutritional and health risks when using the Brazilian 2-item foodinsecurity screen and the EBIA gold standard (Table 4).

Table 2

Contingency table of Brazilian Food Insecurity Scale (EBIA) as gold standard and the 2-item screen tool in identifying food insecure households.

\begin{tabular}{lccc}
\hline 2-item screen & $\begin{array}{c}\text { Identified by EBIA } \\
\mathbf{n}(\%)\end{array}$ & $\begin{array}{c}\text { Not identified by } \\
\text { EBIA } \\
\mathbf{n}(\%)\end{array}$ & $\begin{array}{c}\text { Total } \\
\mathbf{n}(\%)\end{array}$ \\
\hline Identified by the 2-item screen & $644(79.3)$ & $219(7.1)$ & $863(22.0)$ \\
Not identified by the 2-item screen & $168(20.7)$ & $2,889(92.9)$ & $3,057(78.0)$ \\
Total & $812(20.7)$ & $3,108(79.3)$ & $3,920(100.0)$ \\
\hline
\end{tabular}

Table 3

Statistical tests of the 2-item screening tool.

\begin{tabular}{|c|c|c|}
\hline Statistic & Value (\%) & $95 \% \mathrm{Cl}$ \\
\hline Sensitivity & 79.31 & $76.36 ; 82.05$ \\
\hline Specificity & 92.95 & $92.00 ; 93.83$ \\
\hline Positive predictive value & 74.62 & $72.03 ; 77.05$ \\
\hline Negative predictive value & 94.50 & $93.76 ; 95.16$ \\
\hline Accuracy & 90.13 & $89.15 ; 91.04$ \\
\hline $\mathrm{ROC}$ area & 86.13 & $84.67 ; 87.60$ \\
\hline
\end{tabular}

95\% Cl: 95\% confidence interval. 
Table 4

Association of biological variables of children under five years old with food-insecure households by different instruments. Brazilian National Survey of Demography and Health on Women and Children, Brazil, 2006/2007.

\begin{tabular}{|c|c|c|c|c|c|c|c|c|}
\hline \multirow[t]{2}{*}{ Variables } & \multicolumn{4}{|c|}{ EBIA 15-item * } & \multicolumn{4}{|c|}{ 2-item screen * } \\
\hline & CPR $(95 \% \mathrm{Cl})$ & p-value & aPR $(95 \% \mathrm{Cl})$ & p-value & CPR $(95 \% \mathrm{Cl})$ & p-value & aPR $(95 \% \mathrm{Cl})$ & p-value \\
\hline Meat & $1.4(1.2 ; 1.6)$ & 0.001 & $1.2(1.1 ; 1.4)$ & 0.001 & $1.3(1.1 ; 1.4)$ & 0.001 & $1.1(1.1 ; 1.3)$ & 0.022 \\
\hline Fruits \& vegetables & $3.1(2.3 ; 4.1)$ & 0.001 & $1.7(1.3 ; 2.3)$ & 0.001 & $2.6(1.9 ; 3.4)$ & 0.001 & $1.5(1.2 ; 2.0)$ & 0.003 \\
\hline Nutritional status & $1.9(1.5 ; 2.5)$ & 0.001 & $1.4(1.1 ; 1.7)$ & 0.008 & $1.7(1.3 ; 2.2)$ & 0.001 & $1.3(1.1 ; 1.6)$ & 0.047 \\
\hline Hospitalization & $1.6(1.3 ; 2.0)$ & 0.001 & $1.3(1.1 ; 1.6)$ & 0.009 & $1.6(1.3 ; 1.9)$ & 0.001 & $1.4(1.2 ; 1.7)$ & 0.001 \\
\hline
\end{tabular}

95\%Cl: 95\% confidence interval; aPR: adjusted prevalence ratio; cPR: crude prevalence ratio; EBIA: Brazilian Food Insecurity Scale. Note: Poisson regression model.

* Adjusted for: macro-region, urban-rural classification, living conditions, economic status, cash transfer program, maternal education, marital status, number of children in the household, child's gender and age.

\section{Discussion}

The Brazilian 2-item food-insecurity screen showed sensitivity of $79.31 \%$, specificity of $92.95 \%$, positive predictive value of $74.62 \%$, negative predictive value of $94.5 \%$ and ROC area $86.13 \%$. This screen also presented high convergent validity for children's nutrition and health variables when compared with the gold standard, the EBIA full scale, becoming a valid tool to identify families at risk for food insecurity in clinical and other settings.

Food security, when all people at all times have access to sufficient, safe, nutritious food to maintain a healthy and active life 20,21 is a critical part of the ideal environment to raise a child. However, this ideal setting can be disrupted. Difficulty in accessing food can include lack of money to buy food, environmental or health crises such the COVID-19 pandemic, leading families to experience different levels of severity of food insecurity. Access to nutritious food is particularly critical during the first years of life when a child is experiencing rapid growth and brain development 22 . Decreasing food quality and/or quantity - behaviors often seen in food insecure households - are strategies used to avoid experiencing hunger 21.

Over the years, EBIA was incorporated as part of the data collection routine of national/regional surveys 23. Despite the efforts, high implementation costs force long intervals between surveys in Brazil. The Brazilian National Household Sample Survey (PNAD) included EBIA in three of its editions, 2004, 2009 and 2013. The PNDS included EBIA in its 2006 edition. The Brazilian Family Budget Survey (POF) included EBIA for the first time in its 2017/2018 edition. Moreover, its long form demands time and effort, which could heavily interfere with its implementation in the hurried routine of health care professionals in clinical contexts.

Indeed, Brazil enjoys shorter survey versions such as the adult 8-item 24 and the 5 -item scales 25 . However, the country does not yet have a very short screening instrument to promptly assess individual households at risk for food insecurity. The adoption of a 2 -item screen will allow Brazil to rapidly identify families likely living in food-insecure households, thus helping to avoid health and development consequences for children and adults associated with food insecurity and hunger, or responding to immediate crises such as COVID-19. For a more comprehensive assessment of the severity of food insecurity and its prevalence in populations, the longer version of EBIA should be applied.

To assess validity, accuracy and effectiveness of the proposed Brazilian 2-item food insecurity screen, a combination of all seven components of its psychometric profile is required: sensitivity, specificity, positive and negative predictive values, accuracy, area under the ROC curve, and convergent validity.

The proposed Brazilian 2-item food insecurity screen provided sensitivity of $79.3 \%$, attesting satisfactory foundations of the screening test. Moreover, the screen showed specificity of $92.96 \%$, indicating that the screen identifies correctly almost all families that live in food-secure households. 
Supporting this result, the negative predictive value of $94.5 \%$ shows that among those screening negative practically all households were in fact food-secure. Namely, the screen effectively rules out families that are not at risk for food insecurity, avoiding unnecessary interventions and use of financial resources. Furthermore, the Brazilian 2-item food insecurity screen exhibited accuracy of $90.13 \%$ and an area under the ROC curve of $86.13 \%$, indicating acceptable overall ability of the screen to identify households with and without food insecurity based on its results.

The positive predictive value of $74.62 \%$ indicates the proportion of households with a positive screening result that actually are food-insecure. That is, it focuses on the usefulness of the test in clinical practice. Given that the screen is a risk assessment tool, respondents screening positive will further respond to the EBIA full scale. In this sense, the positive predictive value of approximately $25 \%$ of households (false positives) indicates that one quarter of the sample will be responding to the full scale despite being classified as food secure by the gold standard. It leads us to further the discussion on the gold standard food security cut-off point used in this project.

EBIA's sum of affirmative items classifies households into four levels using cutoffs arising from expert discussions informed by psychometric analyses and policy considerations. The cut-off points validated for households with children in Brazil are as follows: Food Secure (0 questions affirmed); Mild Food Insecurity (1-5 questions affirmed); Moderate Food Insecurity (6-10 questions affirmed); and Severe Food Insecurity (11-15 questions affirmed). Consequently, when combining Food Security and Mild Food Insecurity, we considered food secure all households with up to five affirmative responses. That is, some of the false positives are in fact mild food-insecure households. Thus, families in these households might benefit from being classified as positive in the screen, further responding the EBIA full scale to be correctly identified as food secure or insecure. To spark the conversation, a study published in 201626 suggested that, in terms of raw score, Brazilian households endorsing only one item of the scale would be better classified by being placed in the same stratum as those with negative responses on all items, or considered food-secure using EBIA. Thus, we could more appropriately distinguish food-secure from food-insecure households, decreasing the number of false positives in the model.

The correspondence between the food insecurity screen and theoretically related health variables demonstrated by the convergent validity adjusted by socioeconomic and demographic variables showed significance in four variables. These results suggest that EBIA and the Brazilian 2-item food insecurity screen have similar power to capture the negative impacts food insecure pose on children's health. Children living in food-insecure households are more likely to not eat meat or fruits and vegetables every day, to be classified as underweight and be hospitalized by diarrhea or pneumonia. These health conditions suggest increased vulnerability among children living in food-insecure households and the need for immediate referrals to desirable services is imperative.

\section{The Brazilian 2-item food insecurity screen and the COVID-19 pandemic: a practical example of how this tool can be used}

The COVID-19 pandemic has created public health and economic crises worldwide that are likely to test the ability of national, state, and local governments and policymakers to protect their populations from extreme deprivation for an extended period. Constraints on available resources resulting from the worldwide economic downturn will also increase stresses involved in efforts to respond to the need for assistance of all kinds, particularly food assistance 27,28 . In this context, a brief screener to identify families and individuals at risk for food insecurity is urgently needed for use in clinical settings, and by public health workers and social service providers.

In short, the adoption of a Brazilian 2-item food insecurity screen is likely to identify families at risk for food insecurity and place fewer demands on the healthcare system, be more accessible, less expensive and less time-consuming. Besides, the screen can encourage appropriate and timely decision making in times of crisis, such as the one posed by COVID-19 regarding this invisible and harmful condition called food insecurity.

This study has some limitations. First, the authors acknowledge that the methods used for identifying items to be included in a screening tool were systematic and met established standards and the replicability criteria from the HVS set for this study; however, they were not as conservative or rigor- 
ous as item-response theory (IRT) methods. Second, these analyses were conducted using households with at least one child under 5 years of age. Consequently, it is not possible to assert that the 2-item screening tool proposed here would have the same applicability in assessing risk for food insecurity in households containing older children, adults, or older people. Conversely, the HVS validation also used a similar sample, and currently the U.S. tool has been validated to be used in households with youth, adolescents and adults. Therefore, additional validation studies of the proposed Brazilian 2 -item screening tool need to be conducted using samples from older populations and other types of households.

\section{Contributors}

A. Poblacion contributed with the study conception and design, data collection, analysis and interpretation, and writing of the article. A. M. Segall-Corrêa, J. T. Cook and J. A. A. C. Taddei contributed with the study conception and design, data interpretation, and critical review of the manuscript. All authors approved the final version to be published.

\section{Additional informations}

ORCID: Ana Poblacion (0000-0002-5202-3728); Ana Maria Segall-Corrêa (0000-0003-0140-064X); John Cook (0000-0003-0253-229X); Jose Augusto de Aguiar Carrazedo Taddei (0000-0003-3833392X).

\section{References}

1. Pérez-Escamilla R, Segall-Corrêa AM, Maranha LK, Sampaio MFA, Marín-León L, Panigassi G. An adapted version of the U.S. Department of Agriculture Food Insecurity Module is a valid tool for assessing household food insecurity in Campinas, Brazil. J Nutr 2004; 134:1923-8.

2. Hager ER, Quigg AM, Black MM, Coleman SM, Heeren T, Rose-Jacobs R, et al. Development and validity of a 2 -item screen to identify families at risk for food insecurity. Pediatrics 2010; 126:e26-e32.

3. Council on Community Pediatrics; Committee on Nutrition. Promoting food security for all children. Pediatrics 2015; 136:e1431-8.

4. Billioux A, Verlander K, Anthony S, Alley D. Standardized screening for health-related social needs in clinical settings. The accountable health communities screening tool. Washington DC: National Academy of Medicine; 2017.

5. Baer TE, Scherer EA, Fleegler EW, Hassan A. Food insecurity and the burden of health-related social problems in an urban youth population. J Adolesc Health 2015; 57:601-7.

6. Gundersen C, Engelhard EE, Crumbaugh AS, Seligman HK. Brief assessment of food insecurity accurately identifies high-risk US adults. Public Health Nutr 2017; 20:1367-71.

7. Pooler J, Levin M, Hoffman V, Karva F, LewinZwerdling A. Implementing food security screening and referral for older patients in primary care. A resource guide and toolkit. s.l.: AARP Foundation/IMPAQ International; 2016. 
8. Children's HealthWatch. Hunger vital sign translations. http://childrenshealthwatch. org/wp-content/uploads/Hunger-Vital-Sign_ translations.pdf (accessed on 15/Feb/2020).

9. Berquó E, Garcia S, Lago T. Aspectos metodológicos - Pesquisa Nacional de Demografia e Saúde da Criança e da Mulher - PNDS 2006. http://bvsms.saude.gov.br/bvs/pnds/img/ Metodologia_PNDS2006.pdf (accessed on 27/ Nov/2019).

10. Segall-Corrêa AM, Marin-León L, Panigassi G, Pérez-Escamilla R. Segurança alimentar no domicílio. Pesquisa Nacional de Demografia e Saúde da Criança e da Mulher - PNDS 2006: dimensões do processo reprodutivo e da saúde da criança. Brasília: Ministério da Saúde; 2009.

11. Barros AJ, Hirakata VN. Alternatives for logistic regression in cross-sectional studies: an empirical comparison for models that directly estimate the prevalence ratio. BMC Med Res Methodol 2003; 3:20.

12. Poblacion AP, Cook JT, Marín-León L, SegallCorrêa AM, Silveira JA, Konstantyner T, et al. Food insecurity and the negative impact on Brazilian children's health: why does food security matter for our future prosperity? Brazilian National Survey (PNDS 2006/07). Food Nutr Bull 2016; 37:585-98.

13. Segall-Corrêa A, Marín-León L, Panigassi G, Rea M, Pérez-Escamilla R. Amamentação e alimentação infantil. Pesquisa Nacional de Demografia e Saúde da Criança e da Mulher PNDS 2006: dimensões do processo reprodutivo e da saúde da criança. Brasília: Ministério da Saúde; 2009.

14. Ministério da Saúde; Organização Pan-Americana da Saúde. Guia alimentar para crianças menores de dois anos. Brasília: Ministério da Saúde; 2002.

15. Departamento de Atenção Básica, Ministério da Saúde. Dez passos para uma alimentação saudável: guia alimentar para crianças menores de dois anos: um guia para o profissional da saúde na atenção básica. Brasília Ministério da Saúde; 2010.

16. Lohman T, Roche A, Martorell R. Anthropometric standardization reference manual. Champaign: Human Kinectics; 1998.

17. Monteiro C, Conde W, Konno S, Lima A, Silva A, Benicio M. Avaliação antropométrica do estado nutricional de mulheres em idade fértil e crianças menores de cinco anos. Pesquisa $\mathrm{Na}-$ cional de Demografia e Saúde da Criança e da Mulher - PNDS 2006: dimensões do processo reprodutivo e da saúde da criança. Brasília: Ministério da Saúde; 2009.
18. World Health Organization. Child growth standards: length/height-for-age, weight-forage, weight-for-length, weight-for-height and body mass index-for-age: methods and development. Geneva: World Health Organization; 2006.

19. Rao J, Scott A. On chi-squared tests for multiway contingency tables with cell proportions estimated from survey data. Ann Stat 1984; 12:46-61.

20. Cook JT. Clinical implications of household food security: definitions, monitoring, and policy. Nutr Clin Care 2002; 5:152-67.

21. Coleman-Jensen A, Rabbitt MP, Gregory CA, Singh A. Household food security in the United States in 2018. Washington DC: Economic Research Service, U.S. Department of Agriculture; 2019.

22. Cusick SE, Georgieff MK. The role of nutrition in brain development: the golden opportunity of the "First 1000 Days". J Pediatr 2016; 175:16-21.

23. Sperandio N, Morais DC, Priore SE. Escalas de percepção da insegurança alimentar validadas: a experiência dos países da América Latina e Caribe. Ciênc Saúde Colet 2018; 23:449-62.

24. Interlenghi GS, Reichenheim ME, Segall-Corrêa AM, Pérez-Escamilla R, Moraes CL, SallesCosta R. Suitability of the eight-item version of the Brazilian Household Food Insecurity Measurement Scale to identify risk groups: evidence from a nationwide representative sample. Public Health Nutr 2018; [Online ahead of print].

25. Santos LP, Lindemann IL, Motta JV, Mintem G, Bender E, Gigante DP. Proposal of a shortform version of the Brazilian food insecurity scale. Rev Saúde Pública 2014; 48:783-9.

26. Reichenheim ME, Interlenghi GS, Moraes CL, Segall-Corrêa AM, Pérez-Escamilla R, SallesCosta R. A model-based approach to identify classes and respective cutoffs of the Brazilian Household Food Insecurity Measurement Scale. J Nutr 2016; 146:1356-64.

27. Swinnen J, McDermott J. COVID-19 \& global food insecurity. http://ebrary.ifpri.org/utils/ getfile/collection/p15738coll2/id/133762/filename/133971.pdf (accesssed on 10/Mar/2020).

28. Jaime PC. The Covid-19 pandemic: implications for food and nutrition (in)security. Ciênc Saúde Colet 2020; 25:2504. 


\section{Resumo}

O estudo teve como objetivo desenvolver um instrumento de triagem breve com dois itens para identificar famílias brasileiras com filhos em risco de insegurança alimentar. Foram utilizadas análises psicométricas, inclusive sensibilidade, especificidade, valor preditivo positivo e negativo, acurácia e curvas ROC, para testar as combinações de perguntas e determinar o instrumento mais eficaz para avaliar as famílias com risco de insegurança alimentar, comparado a uma escala padrão-ouro. Os participantes pertenciam aos domicílios da Pesquisa Nacional de Demografia e Saúde da Criança e da Mulher (PNDS), usando a resposta à Escala Brasileira de Insegurança Alimentar (EBIA). A amostra incluiu 3.920 domicílios, representando 11.779.686 domicílios quando expandida com os pesos amostrais da PNDS. Com uma prevalência geral de insegurança alimentar de 21\%, o instrumento brasileiro de dois itens para avaliação de insegurança alimentar mostrou sensibilidade 79,31\%, especificidade 92,95\%, valor preditivo positivo $74,62 \%$, valor preditivo negativo $94,5 \%$ e área ROC 86,13\%. O instrumento também apresentou validade convergente alta para as variáveis de nutrição e saúde das crianças, comparado ao padrão-ouro, a EBIA completa. Com base na capacidade de detectar domicílios com risco de insegurança alimentar, esse instrumento de triagem com dois itens é recomendado para adoção geral, enquanto medida de triagem em todo o Brasil, sobretudo durante a pandemia da COVID-19, quando as decisões rápidas são fundamentais. $O$ instrumento pode permitir que os profissionais identifiquem com precisão as famílias em risco de insegurança alimentar e intervenham prontamente para prevenir ou mitigar as consequências adversas para a saúde e o desenvolvimento, associadas à insegurança alimentar, respondendo rapidamente às crises.

Segurança Alimentar; Fome; Epidemiologia Nutricional; Desenvolvimento Infantil

\section{Resumen}

Este trabajo tuvo el objetivo de desarrollar un instrumento breve de 2 items para identificar a los hogares brasileños que incluyen a familias con niños en riesgo de inseguridad alimentaria. Los análisis psicométricos incluyendo sensibilidad, especificidad, valor predictivo positivo y negativo, precisión, y curvas ROC fueron usados para probar combinaciones de preguntas, con el fin de determinar el instrumento más efectivo para evaluar hogares en riesgo de inseguridad alimentaria, cuando se compararon con una escala de estándar de oro. Los participantes incluyeron a los hogares encuestados de la Encuesta Nacional Demográfica sobre la Salud de Mujeres y Niños (PNDS) con una respuesta válida en la Escala de Brasileña de Inseguridad Alimentaria (EBIA). La muestra incluyó 3.920 hogares, representando 11.779.686 hogares, cuando se amplió usando las ponderaciones de la muestra del PNDS. Con la prevalencia general de la inseguridad alimentaria a un 21\%, el instrumento de 2 items brasileño sobre inseguridad alimentaria mostró una sensibilidad de un 79,31\%, especificidad de un 92,95\%, un valor predictivo positivo de $74,62 \%$, un valor negativo predictivo de un 94,50\% y un área ROC de 86,13\%. Este instrumento también presentó una validez convergente alta para la nutrición de los niños y variables de salud, cuando se comparó la escala completa EBIA, el estándar de oro. Basada en su habilidad para detectar hogares en riesgo por inseguridad alimentaria, la herramienta de instrumento de 2 items está recomendada para su amplia adopción, como medida de cribado en todo Brasil, especialmente cuando la toma de decisiones rápidas se ha hecho fundamental, como ante la pandemia de COVID-19. Este método de cribado puede permitir a los proveedores de cuidados identificar con precisión a las familias en riesgo de inseguridad alimentaria e intervenir prontamente para prevenir o mejorar salud adversa y las consecuencias en el desarrollo, relacionadas con la inseguridad alimentaria, así como responder con prontitud a las crisis.

Seguridad Alimentaria; Hambre; Epidemiología Nutricional; Desarrollo Infantil
Submitted on 19/May/2020

Final version resubmitted on $11 / \mathrm{Sep} / 2020$

Approved on 18/Sep/2020 